\title{
THE EFFECT OF SELECTED COMPONENTS OF MILK AND RIPENING TIME ON THE DEVELOPMENT OF THE HARDNESS AND MELTING PROPERTIES OF CHEESE
}

\author{
Krzysztof Młynek ${ }^{1 凶}$, Adam Oler ${ }^{2}$, Karolina Zielińska ${ }^{1}$, Jolanta Tkaczuk ${ }^{1}$, \\ Wiesława Zawadzka ${ }^{1}$
}

\author{
${ }^{1}$ Department of Cattle, Sheep Breeding and Milk Evaluation, Siedlce University of Natural Sciences and Humanities \\ Prusa 14, 08-110 Siedlce, Poland \\ ${ }^{2}$ Department of Cattle Breeding, UTP University of Science and Technology \\ Mazowiecka 28, 85-084 Bydgoszcz, Poland
}

\begin{abstract}
Background. The growing interest in ripening cheeses in Poland has increased milk production, which enhances the need to improve its quality. One method is to increase the fat and casein content of milk. In effect, the proportions of these ingredients affect production efficiency and quality of cheese. Most milk components, and the maturity of the cheese, are associated with two qualities which are very important for consumers, hardness and fusibility. Therefore, the complex proteolysis and lipolysis processes occurring in ripening cheeses are an important evaluation component. For this reason, there is a constant need to deepen the knowledge of the relationships between the components of bulk milk and those retained in curds, and the processes that shape the quality of ripening cheese, which is important for consumers. The aim of the study was to analyze the transformations of proteins and fat which occur during the ripening of Gouda cheese. Research hypotheses assumed that higher proportions of fat in milk and curd were associated with melting properties and that the casein content in milk and protein content in curds affected the brittleness and greater nitrogen recovery in cheese.

Materials and methods. The research materials consisted of 15 cheese batches, produced from October to December. Cheese samples were collected at several ripening stages (RS): day $1^{\text {th }}, 14^{\text {th }}, 30^{\text {th }}$ and $60^{\text {th }}$. Bulk milk was subjected to standard procedures applied during Gouda cheese production. Fat was extracted from the cheese, the content of which was estimated on the basis of fat values. The intensity of proteolysis was determined by the content of soluble nitrogen and nitrogen recovery. The data was statistically compiled using the ANOVA mixed model. The influence of the ripening stage, differences between means and the correlation coefficient values were estimated at $P \leq 0.05$.

Results. The results confirmed that ripening stage has a strong influence on the increase in dry matter content and nitrogen solubility and the decrease in fat content in cheese. Assessment of proteolytic changes (the proportion of soluble nitrogen, NS) indicates an increased dynamic of changes from day $30^{\text {th }}$ of ripening. This index was correlated with casein and dry matter content. However, the amount of nitrogen recovered in cheese (NR) was most strongly correlated with protein content in the product and casein content in bulk milk. The ripening time was related to the melting properties and hardness of the cheese, as evidenced by the values of the correlation coefficient $(0.394$ and 0.489$)$. Both characteristics were also related to the fat content in milk and in cheese $(-0.286$ to -0.427$)$. Moreover, hardness was correlated with the proportion of protein, dry matter and casein in milk (0.326-0.762). The influence of RS on the increase in the acid and saponification values of fat contained in the cheese was usually observed from the $30^{\text {th }}$ day of ripening $(0.512$ and 0.535$)$. These changes were accompanied by a decrease in fat content $(r=-0.247$ and -0.364$)$.
\end{abstract}

\footnotetext{
『krzysztof.mlynek@uph.edu.pl
} 


\begin{abstract}
Conclusions. The recorded range of changes do not affect the nutritional values of cheese, as free fatty acid content increased only slightly with ripening time. The observed tendencies towards slower proteolysis and lipolysis reactions can be partly explained by the increasing content of dry matter (lower water availability). It was shown that the proportion of fat in milk and cheese and its protein content significantly affected the hardness and melting properties of cheese. Importantly, the proportion of casein in milk was positively associated with nitrogen recovery in the ripening product. It can be assumed that the activities increasing the proportion of casein in milk are an important method of improving the technological suitability and sensory quality of cheese.
\end{abstract}

Keywords: ripening-cheese, correlation, physico-chemical properties, casein, fat values

\title{
INTRODUCTION
}

Amongst other factors, the quality of ripening cheeses results from milk quality and processing technology (Chilliard et al., 2007; Coulon et al., 2004). The length of time and conditions under which cheeses are ripened may also lead to substantial economic losses if the presence of microorganisms causes undesirable changes (Basilico et al., 2001; Guinee and Fox, 2008). One of the indicators of the usefulness of milk used for the production of cheese is protein and fat content, the transformations of which shape many important quality characteristics of hard cheeses. Factors affecting the proportion of components that determine the usefulness of milk for cheese production play a significant role in this matter (Bugaud et al., 2001; Bovolenta et al., 2014). Casein is of course the most basic, but milk fat, and especially its quality, is equally important (Chilliard et al., 2007; Ferlay et al., 2008; Slots et al., 2009). It is of great importance due to lipolytic changes (Hayaloglu, 2009) and protein proteolysis (Yvon and Rijnen, 2001), which are the main mechanisms that cause cheese ripening. Most of the transformations of milk lipids to free fatty acids and glycerol, as well as mono- and diacylglycerides, (Deeth and Touch, 2000) are associated with enzymatic processes (Collins et al., 2003; Jaros et al., 2001; McSweeney and Sousa, 2000). The proportion of chemical products resulting from these changes, according to Bugaud et al. (2001), determines the flavor and taste profile of ripening cheeses. Lipids, and especially polyunsaturated fatty acids that undergo oxidation or hydrolytic degradation (McSweeney and Sousa, 2000) are particularly susceptible to changes leading to aldehyde formation. Processes which occur during cheese formation include transformations of complex compounds contained in the curd into simple substances formed during ripening. These compounds may, under certain conditions, cause defects in taste and texture (McSweeney and Sousa, 2000; Yvon and Rijnen, 2001). As well as the quality of lipids, the proportion of milk fat remaining in the curd is important for quality. This was indicated in the studies by Mistry (2001), Nelson and Barabano (2004) and Guinee et al. (2000), who showed that the reduction of this component in various types of cheeses usually caused changes unacceptable to consumers. The degree of lipid metabolism during cheese ripening can be determined, amongst other methods, by the saturation and content of free fatty acids and changes in specific weight, while proteolytic transformations can be determined by the degree of nitrogen solubility in water (Wallace and Fox, 1997; Yildirim et al., 2006).

The main aim of the study was to analyze the transformations of lipids which occur during Gouda cheese ripening. Therefore, the strength of relationship between the content of milk components and selected indicators of cheese ripening was estimated, alongside its hardness and melting properties. Research hypotheses assumed that a higher proportion of fat in milk resulted in higher melting properties, and casein content increased hardness and nitrogen recovery during cheese ripening.

\section{MATERIALS AND METHODS}

Research materials consisted of 15 batches of Gouda-type cheese, produced from separate milk tanks, 
collected from October to December. Milk complying with the standard (EC; No. 1662/2006) was used for milk production. The content $(\%$; average, minimummaximum) of: protein $=3.78 ; 3.73-3.82$; fat $=3.54$; $3.45-3.59$; lactose $=4.58 ; 4.53-4.69 ;$ casein $=2.93$; $2.84-3.08$ and total nitrogen $=0.593 ; 0.584-0.599$ was determined in the bulk milk. The average milk quantity (l) used to produce a batch of cheese $=117875$; 82 400-121 100. In the experiment, all analyses were performed at least in triplicate.

\section{Cheese production}

The milk was pasteurized $\left(72^{\circ} \mathrm{C} / 15 \mathrm{~s}\right)$ and bactofugated, and the proteins were concentrated by microfiltration to a target level of $3.8 \%$. Cold milk $\left(8^{\circ} \mathrm{C}\right)$ was stored $(12-48 \mathrm{~h})$. After this time, the raw material was inoculated with starter cultures (Lactococcus $)$, thermized $\left(68^{\circ} \mathrm{C} / 30 \mathrm{~min}\right)$ and then cooled $\left(32^{\circ} \mathrm{C}\right)$ and treated with cultures of lactic bacteria (R-603, $\mathrm{Hr}$ Hansen; $500 \mathrm{~g} / 600001$ of milk). Thermization and pasteurization of milk was performed on plate heat exchangers (Front 8-FRM, AlfaLaval). A coagulating enzyme (Fromase) was added at this stage. The level of bacterial culture added was selected in proportions which produced a $\mathrm{pH}$ of 5.25 to 5.45 in compressed blocks. The curd was sliced and dried after about 35 min. Curd acidity (pH 6.25-6.35) was stabilized by whey drainage (about $45 \%$ ) and the addition of water $(25 \%)$. Time to grain separation did not exceed $2 \mathrm{~h}$. The curd separation process was accelerated by heating $\left(38^{\circ} \mathrm{C} / 30 \mathrm{~min}\right)$. The resulting curd was set into blocks of approximately $15.5 \mathrm{~kg}$, on pressure presses (Formatic, $2.5 \mathrm{~h}$, initial strength $0.08 \mathrm{MPa}$ - final 0.59 $\mathrm{MPa}$ ). The obtained blocks were subjected to a brine bath $(\mathrm{pH} 4.6-4.9$, salt concentration $19-21 \%$, temperature of $14-16^{\circ} \mathrm{C}$, time $-48 \mathrm{~h}$ ). The dried cheese was vacuum-packed in foil (M.EMVAC - PA/adhesive/PE). The blocks were then placed in the ripening room (humidity $80 \%$, stage I $-6^{\circ} \mathrm{C} / 7$ days, stage II $12^{\circ} \mathrm{C} /$ till day 60$)$.

\section{Collection and preparation of the experimental material (cheese, fat)}

From 15 randomly selected blocks of the cheese at several ripening stages (RS), the experimental material was collected (about $400 \mathrm{~g}$ ). After collecting the samples, the blocks were packed again. The sampling was performed on day $1^{\text {th }}(\mathrm{RS}-\mathrm{I})$ and after $14^{\text {th }}(\mathrm{RS}-\mathrm{II})$, $30^{\text {th }}$ (RS-III) and $60^{\text {th }}$ days (RS-IV). Fat was extracted from the fragmented and dried $\left(105^{\circ} \mathrm{C}\right)$ cheese (Soxhlet; AOAC, 2000). The obtained extracts were further dried $\left(\right.$ at $\left.105^{\circ} \mathrm{C}\right)$ and stored until analysis $\left(\right.$ at $\left.-20^{\circ} \mathrm{C}\right)$.

\section{Analytical procedures used for milk}

Analyses: temperatures (calibrated thermometer), acidity ${ }^{\circ} \mathrm{SH}$ (AOAC, 2000) basic component contents (Milco Scan FT 120), antibiotics and inhibitors (testCharm MRL BL3, Delvotest-SP), total nitrogen (Kjeldahl; IDF, 2002).

\section{Procedures used for cheese and fat analysis}

Acidity (Metler Toledo pH-meter), dry mass (dryer weight), content of: fat (Soxhlet; AOAC, 2000) and total nitrogen (Kjeldahl; IDF, 2002), hardness $\left[\mathrm{N} / \mathrm{cm}^{2}\right]$. Analysis was performed on cylindrical samples of cheese ( $20 \mathrm{~mm}$ in diameter and $20 \mathrm{~mm}$ in legth) evaluated with a texture analyzer (TA.XT Express Enhanced; Stabile Mikro Systems UK). Melting time was measured with a stopwatch from the moment of placing the sample base $(10 \times 10 \mathrm{~mm})$ on a teflon plate $\left(80^{\circ} \mathrm{C}\right)$ until a flat form was obtained.

The intensity of changes in the lipid fraction was evaluated on the basis of fat values: acid index - AI, mg $\mathrm{NaOH} / 1 \mathrm{~g}$; iodine index $-\mathrm{JI}, \mathrm{g} \mathrm{I} / 100 \mathrm{~g}$; saponification index - SI, mg NaOH/100 g. Nitrogen recovery (NR) was calculated on the basis of the total nitrogen content in bulk milk and cheese. The range of proteolysis during cheese ripening was determined by the content of soluble nitrogen - SN-TCA (pH 4.6 in $12 \%$ trichloroacetic acid - TCA; Leclercq-Perlat et al., 2000).

\section{Statistical analysis}

Data was statistically analyzed using the mixed model ANOVA, in which month of milk collection (general milk characterization) and cheese ripening time (the main part of the research) were used as factors. The analysis used SSQ matrices. The data is presented as means, standard deviation (SD) and $P$ value, indicating the significance of the effect of a given factor on the tested trait. Differences between group means were tested using Duncan's test (level of significance set at 5\%). Pearson's correlation coefficient was used to determine the strength of the interrelationship between selected traits $(P \leq 0.05)$. 


\section{RESULTS AND DISCUSSION}

The changes in cheese acidity $(\mathrm{pH})$ from 5.25 to 5.47 presented in Table 1 confirmed a small but significant effect of the ripening stage (RS; $P \leq 0.048$ ) on this index. The highest rate of change was observed in the period up to the $30^{\text {th }}$ day of ripening. Trends observed in the current study were similar to those obtained by Yildirim et al. (2006), who observed increasing pH until day $30^{\text {th }}$ of ripening. Acidity reduction was observed at a later stage. These results are consistent with those reported by Bovolenta et al. (2014), who reported that the $\mathrm{pH}$ after 60 days of ripening was, on average, 5.30. Slightly lower $\mathrm{pH}$ values were demonstrated by Johnson et al. (2001), who found an average of 5.33 at the beginning of ripening, and from the second week they ranged from 5.04 to 5.21. The study of Johnson et al. (2001) demonstrated that curd acidification $(\mathrm{pH}<5.0)$ in the final stage of production may involve the risk of unfavorable quality changes during cheese reheating. According to these authors, this was related to casein dehydration and phosphoserine release into the whey and, as reported by Kellar et al. (1974), impaired binding of calcium ions. The result may be excessive granulation and brittleness of the curd mass.

Table 1 shows that the ripening stage (RS) was strongly associated with dry matter content $(P=$ $0.001)$, nitrogen water solubility (NS; $P=0.022)$ and fat content $(P=0.024)$. The highest dry matter values were observed in RS-III and RS-IV (average of $58.35 \%$ ), and they were higher by 1.22 and $0.71 \mathrm{pp}$ respectively, in comparison to cheese evaluated in RS-I and RS-II $(P \leq 0.05)$. A higher dry matter content - on average, $66.6 \%$ on the $60^{\text {th }}$ day of cheese ripening - was shown by Bovolenta et al. (2014). The trends in dry matter content changes obtained in our study remained consistent with those reported by Yildirim et al. (2006). It should be noted that despite the differences in dry matter content reported, the level of this component in the RS tested was not subject to high variability (SD: 0.48-0.78), which supports the conclusions of Yildirim et al. (2006). The evaluation of proteolytic changes analyzed on the basis of soluble nitrogen percentage (NS; Table 1) showed the highest intensity between RS-II and RS-III $(0.20 \%, P \leq 0.05)$. They were less intense in subsequent stages, and the average difference was $0.11 \%(P \leq 0.05)$. These results were confirmed by Yildirim et al. (2006), in which the amount of soluble nitrogen increased with the ripening time, ranging from 0.25 to $0.65 \%$. The effect of RS on NS shown in Table 1 was confirmed by the value of the correlation coefficient (0.456; Table 3$)$. It was also found that NS correlated with the proportion of casein in milk (0.398) and dry matter content $(-0.319)$, which might explain the slowing down of protein degradation and lipolysis due to lower water availability.

Table 1. The chemical composition of cheese from different ripening stages

\begin{tabular}{|c|c|c|c|c|c|c|}
\hline \multirow{2}{*}{ Traits } & \multicolumn{4}{|c|}{ Ripening stages $-\mathrm{RS}, n=15$} & \multirow{2}{*}{ Average } & \multirow{2}{*}{$P$-value } \\
\hline & I (1 day) & II (30 days) & III (60 days) & IV (90 days) & & \\
\hline \multicolumn{7}{|l|}{ Content, \% } \\
\hline Dry matter & $57.13^{\mathrm{a}} \pm 0.48$ & $57.64^{b} \pm 0.64$ & $58.24^{\mathrm{c}} \pm 0.58$ & $58.47^{\mathrm{c}} \pm 0.72$ & $57.87 \pm 0.78$ & 0.001 \\
\hline Crude fat & $27.57^{\mathrm{a}} \pm 0.94$ & $25.29^{\mathrm{b}} \pm 0.83$ & $24.56^{c} \pm 0.79$ & $24.32^{\mathrm{c}} \pm 0.89$ & $25.44 \pm 0.93$ & 0.024 \\
\hline Crude protein & $28.40 \pm 0.97$ & $29.41 \pm 1.15$ & $29.49 \pm 0.88$ & $29.59 \pm 0.95$ & $29.24 \pm 0.99$ & 0.439 \\
\hline Total nitrogen & $4.55 \pm 0.15$ & $4.61 \pm 0.18$ & $4.78 \pm 0.13$ & $4.95 \pm 0.14$ & $4.72 \pm 0.15$ & 0.245 \\
\hline Nitrogen recovery - NR, \% & $76.11^{\mathrm{a}} \pm 1.43$ & $77.52^{b} \pm 1.66$ & $78.87^{\mathrm{c}} \pm 1.32$ & $78.94^{\mathrm{c}} \pm 2.68$ & $77.88 \pm 1.96$ & 0.048 \\
\hline Soluble nitrogen - SN-TCA, \% & $0.29^{\mathrm{a}} \pm 0.11$ & $0.37^{\mathrm{a}} \pm 0.12$ & $0.57^{b} \pm 0.09$ & $0.68^{\mathrm{c}} \pm 0.07$ & $0.48 \pm 0.10$ & 0.022 \\
\hline $\mathrm{pH}$ & $5.25^{\mathrm{a}} \pm 0.12$ & $5.47^{\mathrm{a}} \pm 0.10$ & $5.34^{b} \pm 0.08$ & $5.33^{b} \pm 0.09$ & $5.35 \pm 0.97$ & 0.048 \\
\hline
\end{tabular}

a,b,c Statistically significant differences at $p \leq 0.05$. 
The proportion of fat content decreased from $27.57 \%$ (RS-I) to $24.32 \%$ (RS-IV). However, the greatest change was observed before day 30 day of ripening, which amounted to $2.28 \mathrm{pp}$. The differences ranged from 0.73 to $0.24 \%$ in successive RSs $(P \leq 0.05)$. Pluta et al. (2006) found similar tendencies, as fat content in their study decreased from 0.2 to $1.2 \%$ in week 6 and 8 of ripening respectively. In turn, Mei et al. (2015) recorded an average decrease in the proportion of fat of $3.03 \%$ over the first 35 days of ripening. According to these authors, this trend was associated mainly with the intensity of lipolysis. Mei et al. (2015) and Kondyli et al. (2002) also showed that the decreasing fat content was accompanied by an increase in fat hydrolysis (ADV). The average ADV values obtained by them on day 35 of cheese ripening was $7.17 \mathrm{mg} \mathrm{KOH} / 100 \mathrm{~g}$. It was found that ripening phase had a significantly lower influence RS $(P \leq 0.048)$ on the amount of NR nitrogen recovered in cheese (Table 1). The observed trends were similar to those for dry matter content change. The NR value in the analyzed time period increased from $76.11 \%$ (RS-I) to an average of $78.91 \%$ in RS-III and RS-IV. The differences ranged from $1.38 \%$ to $1.41 \%(P \leq 0.05)$. The NR value was most strongly correlated (Table 3 ) with the proportion of protein in ripening cheese $(0.568)$ and casein in cheese milk (0.419). However, the effect of RS on NR had a smaller impact ( $r=0.288$; Table 3$)$. Research conducted by Kim et al. (2004) showed that casein is the most rapidly proteolyzed of the proteins contained in cheese. This explains the relationship between casein content in cheese milk and water-soluble nitrogen recorded in our study.

Lipolysis is an integral process during cheese ripening, which, by affecting the chemical quality of fats, may also determine its hardness and melting properties. It was demonstrated that the effect of RS was stronger for cheese melting properties $(P=0.003)$ than its hardness $(P=0.028$; Table 2$)$. This was also confirmed by the values of the correlation coefficient 0.394 and 0.489 respectively (Table 3 ). A longer melting time was generally observed in cheeses evaluated in later RSs. The lowest values of this index were recorded in RS-I and RS-II (51.7 s on average), which was shorter by an average of $3.65 \mathrm{~s}$ than that found in RS-III and RS-IV $(P \leq 0.05)$. This relationship was confirmed by the correlation coefficient $(0.489$; Table $3)$. It was also shown that melting time was correlated with fat content in cheese milk $(-0.293)$ and in cheese $(-0.427)$. The obtained results indicated that higher fat content had a positive effect on obtaining lower cutting values, by which hardness was measured.

With respect to cheese hardness, an increase in cutting force was usually observed towards day $60^{\text {th }}$ of ripening. The value of this trait in RS-III and RS-IV was $0.325 \mathrm{~N} / \mathrm{cm}^{2}$, and was higher than in RS-I and RS-II from 0.09 to $0.06 \mathrm{~N} / \mathrm{cm}^{2}(P \leq 0.05)$. It should be noted that the highest correlation for cheese hardness was recorded for protein content in cheese $(0.762)$ and dry matter (0.620) and casein content in milk (0.326). Kim et al. (2004) obtained similar values of the correlation coefficient between cheese hardness and protein

Table 2. The chemical composition of cheese and fat cheese from different ripening stages

\begin{tabular}{|c|c|c|c|c|c|c|}
\hline \multirow{2}{*}{ Traits } & \multicolumn{4}{|c|}{ Ripening stages $-\mathrm{RS}, n=15$} & \multirow{2}{*}{ Average } & \multirow{2}{*}{$P$-value } \\
\hline & I (1 day) & II (30 days) & III (60 days) & IV (90 days) & & \\
\hline Hardness, $\mathrm{N} / \mathrm{cm}^{2}$ & $0.24^{\mathrm{a}} \pm 0.07$ & $0.27^{\mathrm{b}} \pm 0.09$ & $0.32^{\mathrm{c}} \pm 0.07$ & $0.33^{c} \pm 0.08$ & $0.29 \pm 0.09$ & 0.028 \\
\hline Melting, s & $51.5^{\mathrm{a}} \pm 2.9$ & $51.9^{\mathrm{a}} \pm 2.2$ & $55.0^{\mathrm{b}} \pm 3.0$ & $55.7^{\mathrm{b}} \pm 37$ & $53.5 \pm 3.4$ & 0.003 \\
\hline \multicolumn{7}{|l|}{ Fat values: } \\
\hline Saponification index $-\mathrm{SI}, \mathrm{mg} \mathrm{KOH} / 100 \mathrm{~g}$ & $189^{\mathrm{a}} \pm 38$ & $195^{\mathrm{a}} \pm 21$ & $2019^{b} \pm 15$ & $231^{\mathrm{b}} \pm 18$ & $208 \pm 22$ & 0.035 \\
\hline Iodine index $-\mathrm{JI}, \mathrm{g} \mathrm{I}_{2} / 100 \mathrm{~g}$ & $31.3 \pm 2.4$ & $32.1 \pm 3.6$ & $33.5 \pm 2.3$ & $33.9 \pm 2.0$ & $32.7 \pm 2.7$ & 0.063 \\
\hline Acid index $-\mathrm{AI}, \mathrm{mg} \mathrm{KOH} / 1 \mathrm{~g}$ & $1.19^{\mathrm{a}} \pm 0.07$ & $1.28^{\mathrm{b}} \pm 0.04$ & $1.33^{\mathrm{c}} \pm 0.03$ & $1.32^{\mathrm{c}} \pm 0.04$ & $1.28 \pm 0.9$ & 0.001 \\
\hline
\end{tabular}

a,b,c Statistically significant differences at $p \leq 0.05$. 
Młynek, K., Oler, A., Zielińska, K., Tkaczuk, J., Zawadzka, W. (2018). The effect of selected components of milk and ripening time on the development of the hardness and melting properties of cheese. Acta Sci. Pol. Technol. Aliment., 17(2), 133-140. http://dx.doi. org/10.17306/J.AFS.2018.0549

Table 3. Coefficients of Pearson's correlation of chemical composition and physical properties of bulk milk and cheese with traits of ripening cheese

\begin{tabular}{|c|c|c|c|c|c|c|c|}
\hline & \multicolumn{7}{|c|}{ Cheese } \\
\hline & $\begin{array}{c}\text { hardness } \\
\mathrm{N} / \mathrm{cm}^{2}\end{array}$ & melting, $\mathrm{s}$ & SI & JI & AI & NR, \% & SN-TCA, \% \\
\hline \multicolumn{8}{|l|}{ Milk } \\
\hline Crude protein, $\%$ & 0.153 & 0.029 & $0.395^{*}$ & $0.393^{*}$ & $0.509^{*}$ & -0.224 & 0.234 \\
\hline Casein, $\%$ & $0.326^{*}$ & - & 0.278 & 0.242 & 0.124 & $0.419 *$ & $0.398^{*}$ \\
\hline Crude fat, $\%$ & $-0.311^{*}$ & $-0.456^{*}$ & $0.647^{*}$ & $0.635^{*}$ & $0.552 *$ & -0.159 & - \\
\hline \multicolumn{8}{|l|}{ Cheese } \\
\hline Ripening stages - RS, day & $0.394 *$ & $0.489 *$ & $0.512 *$ & 0.299 & $0.535^{*}$ & $0.288^{*}$ & $0.456^{*}$ \\
\hline Crude fat, $\%$ & $-0.286^{*}$ & $-0.427 *$ & $-0.247^{*}$ & 0.207 & $-0.364 *$ & $-0.245^{*}$ & - \\
\hline Dry matter, \% & $0.620 *$ & $0.617^{*}$ & $-0.317^{*}$ & - & $-0.410^{*}$ & $-0.235^{*}$ & - \\
\hline Crude protein, $\%$ & $0.762 *$ & $0.273^{*}$ & -0.116 & - & - & $0.568 *$ & - \\
\hline Total nitrogen, $\%$ & 0.216 & 0.236 & - & - & - & $0.369^{*}$ & 0.249 \\
\hline Hardness, N/cm ${ }^{2}$ & - & - & -0.256 & 0.195 & $0.322 *$ & - & - \\
\hline Melting, s & - & - & $-0.390^{*}$ & - & $0.339 *$ & - & - \\
\hline
\end{tabular}

$* P \leq 0.05$.

SI - saponification index, JI - iodine index, AI - acid index, NR - nitrogen recovery, SN-TCA - soluble nitrogen.

hydrolysis products. Surprisingly, a significantly lower correlation value was found for fat content $(-0.286$; Table 3).

Milk fat is characterized by a relatively high proportion of saturated acids, which can be esterified to a certain extent by lipolytic enzymes. The degree of fat saturation, which is conducive to oxidation processes, may therefore be significant for traits formed during ripening of cheese. The results regarding fat values presented in Table 2 indicate that the most rapid changes in cheese lipid fraction occurred during the initial RS. The values found to be most strongly affected by ripening stage (RS) were acid value (LK; $P=0.001)$ and saponification value (LZ; $P=0.035)$. The greatest difference in the content of free fatty acids (LK) was found between RS-I and RS-II $(0.09 \mathrm{mg} / \mathrm{g}$; $P \leq 0.05)$. The pace of these changes in subsequent RS (III and IV) clearly decelerated, and the differences varied from 0.05 to $0.01 \mathrm{mg} / \mathrm{g}(P \leq 0.05)$. This tendency was confirmed by the correlation coefficient value of $0.535(P \leq 0.05)$. The content of free fatty acids and fatty acids esterified with fat, estimated on the basis of the saponification value - LZ, showed slight changes (Table 2). The highest difference was found between days 30 and 60 of ripening $(6.0 \mathrm{mg} / 100 \mathrm{~g})$. However, it should be noted that greater variation in this trait was found in the initial ripening period (SD: $38-21$ $\mathrm{mg} / 100 \mathrm{~g} ; P \leq 0.05)$. This trend was confirmed by the value of the correlation coefficient $(0.512 ; P \leq 0.05)$. Polentarutti et al. (2001) showed that short-chain fatty acids were predominantly produced during the 60-day ripening of Montasio cheese. This may, therefore, explain the tendency observed in our study with respect to fat values, indicating a slight increase in the content of lower molecular weight compounds in more ripened cheese. The range of changes observed does not have a significant impact on the nutritional values of cheese. In this respect, the absence of the effect of the ripening stage on changes in fatty acid non-saturation (iodine value; $P=0.063$ ) is positive. It can be concluded, based on dry matter results (Table 1) and LK and LZ values, that lipolysis was the main 
Młynek, K., Oler, A., Zielińska, K., Tkaczuk, J., Zawadzka, W. (2018). The effect of selected components of milk and ripening time on the development of the hardness and melting properties of cheese. Acta Sci. Pol. Technol. Aliment., 17(2), 133-140. http://dx.doi. org/10.17306/J.AFS.2018.0549

cause of decreasing fat content in cheese during the ripening period. This was also confirmed by correlation coefficient values (Table 3 ) between fat content and LZ $(-0.241 ; P \leq 0.05)$ and LK $(-0.364 ; P \leq 0.05)$. These results are consistent with the study of Mei et al. (2015), in which the degree of lipolysis was estimated based on the total concentration of free fatty acids. They showed that the content of free fatty acids increased from 456.35 at the beginning of ripening to $935.91 \mathrm{mg} / \mathrm{kg}$ on day 35 day, with a simultaneous decrease in fat content.

\section{CONCLUSIONS}

The results show the hardness and meltability of the analysed cheese to be equiparably related with the fat content in the milk and cheese and with lipid transformations during ripening. The fat content in cheesemaking milk was found to potentially play an essential role in lipid transformations during cheese ripening. The observed trend can be due to the ripening timespan and water availability that inhibited the development of changes in the lipid fraction. It is worth noting that the most intensive changes occurred by the $60^{\text {th }}$ day of ripening. It was also found that cheese hardness was affected by the protein content in the cheese to a greater extent than by the casein content in the cheese-making milk. On the other hand, higher casein content had a positive effect on nitrogen recovery in the ready-made product. It can be assumed that improvements in the production efficiency and hardness and meltability of ripened cheeses can be enhanced i.a. by measures taken to increase the casein and fat contents in milk. This information is vital as the discussed factors are highly valued by consumers. This fact and the production profitability aspect are also important for producers of ripened cheeses.

\section{REFERENCES}

AOAC (2000). Official methods of analysis. $17^{\text {th }}$ ed. Vol. 2. Association of Official Analytical Chemists.

Basilico, J. C., DeBasilico, M. Z., Chiericatti, C., Vinderola, C. G. (2001). Characterization and control of mould thread in cheese. Lett. Appl. Microbiol., 32, 6, 419. https://doi.org/10.1046/j.1472-765X.2001.00934.x
Bovolenta, S. A., Romanzin, M., Corazzin, M., Spanghero, E., Aprea, F., Gasperi, E. (2014). Piasentier volatile compounds and sensory properties of montasio cheese made from the milk of Simmental cows grazing on alpine pastures. J. Dairy Sci., 97, 7373-7385. https://doi. org/10.3168/jds.2014-8396

Bugaud, C., Buchin, S., Hauwuy, A., Coulon, J. B. (2001). Relationships between flavour and chemical composition of Abondance cheese derived from different types of pastures. Lait, 81, 757-773. https://doi.org/10.1051/ lait:2001162

Buccioni, A., Rapaccini, S., Antongiovanni, M., Minieri, S., Conte, G., Mele, M. (2010). Conjugated linoleic acid and C18:1 isomers content in milk fat of sheep and their transfer to Pecorino Toscano cheese. Int. Dairy J., 20, 3, 190-194. https://doi.org/10.1016/j.idairyj.2009.10.001

Chilliard, Y. F., Glasser, A., Ferlay, L., Rouel, B. J., Doreau, M. (2007). Diet rumen biohydrogenation and nutritional quality of cow and goat milk fat. Eur. J. Lipid Sci. Technol., 109, 828-855. http://DOI.org/10.1002/ ejlt. 200700080

Collins, Y. F., Mc'Sweeney, P. L. H., Wilkinson, M. G. (2003). Lipolysis free fatty acid catabolism in cheese: a review of current knowledge. Int. Dairy J. 13, 841866. https://doi.org/10.1016/S0958-6946(03)00109-2

Commission Regulation (EC) No 1662/2006 of 6 November 2006 amending Regulation (EC) No 853/2004 of the European Parliament and of the Council laying down specific hygiene rules for food of animal origin.

Coulon, J. B., Delacroix-Buchet, A., Martin, B., Pirisi, A. (2004). Relationships between ruminant management and sensory characteristics of cheeses: A review. Lait, 84, 221-241. https://doi.org/10.1051/lait:2004008

Deeth, H. C., Touch, V. (2000). Methods for detecting lipase activity in milk and milk products. Aust. J. Dairy Technol., 55, 153-168.

Ferlay, A., Agabriel, C., Sibra, C., Journal, C., Martin, B., Chilliard, Y. (2008). Tanker milk variability in fatty acids according to farm feeding and husbandry practices in a French semi-mountain area. J. Dairy Sci. Technol., 88, 193-215. https://doi.org/10.1051/dst:2007013

Guinee, T. P., Auty, M. A. E., Fenelon, M. A. (2000). The effect of fat content on the rheology. microstructure and heat-induced functional characteristics of Cheddar cheese. Int. Dairy J., 10, 277-288. http://dx.doi. org/10.1016/S0958-6946(00)00048-0

Guinee, T. P., Fox, P. F. (2008). Salt in cheese: physical, chemical and biological aspects. In: P. Fox, P. McSweeney, T. Cogan, T. Guinee (Eds.), Cheese: chemistry, physics and microbiology (vol. 1, pp. 207-259). 3th ed. Elsevier. 
Hayaloglu, A. A. (2009). Volatile composition and proteolysis in traditionally produced mature Kashar cheese. Int. J. Food Sci. Technol., 44, 1388-1394. http://doi. org/10.1111/j.1365-2621.2009.01968.x

IDF (2002). Milk. Determination of nitrogen content (Kjeldahl method) and calculation of crude protein content. IDF Standard 20-I. International Dairy Federation.

Jaros, D., Petrag, J., Rohm, H., Ulberth, F. (2001). Milk fat composition affects mechanical and rheological properties of processed cheese. Appl. Rheol., 11, 19-25.

Johnson, M. E., Chen, C. M., Jaeggi, J. J. (2001). Effect of rennet coagulation time on composition, yield, and quality of reduced-fat Cheddar cheese. J. Dairy Sci., 84, 1027-1033. https://doi.org/10.3168/jds.S0022-0302(01) 74562-6

Kellar, B., Olson, N. F., Richardson, T. (1974). Mineral retention and rheological properties of Mozzarella cheese made by direct acidification. J. Dairy Sci., 57, 174-180.

Kim, S. Y., Gunasekaran, S., Olson, N. F. (2004). Combined use of chymosin and protease from Cryphonectria parasitica for control of meltability and firmness of Cheddar cheese. J. Dairy Sci., 87, 2, 274-283. https://doi. org/10.3168/jds.S0022-0302(04)73166-5

Kondyli, E., Katsiaria, M. C., Masourasb, T., Voutsinasa, L. P. (2002). Free fatty acids and volatile compounds of low-fat Feta-type cheese made with a commercial adjunct culture. Food Chem., 79, 199-205. https://doi. org/10.1016/S0308-8146(02)00132-2

Leclercq-Perlat, M. N., Oumer, A., Buono, F., Bergere, J. L., Spinnler, H. E., Corrieu, G. (2000). Behavior of Brevibacteriu mlinens and Debaryomyces hansenii as ripening flora in controlled production of soft smear cheese from reconstituted milk: Protein degradation. J. Dairy Sci., 83, 1674-1683. https://doi.org/10.3168/jds.S00220302(00)75036-3

Martin, B., Verdier-Metz, I., Buchin, S., Hurtaud, C., Coulon, J. B. (2005). How does the nature of forages and pastures diversity influence the sensory quality of dairy livestock products? Anim. Sci., 81, 205-212. https://doi. org/10.1079/ASC50800205

McSweeney, P. L. H., Sousa, M. J. (2000). Biochemical pathways for the production of flavour compounds in cheeses during ripening: A review. Lait, 80, 293-324.
Mei, M., Guo, Q., Wu, Y., Li, Y., Yu, H. (2015). Study of proteolysis, lipolysis, and volatile compounds of a Camembert-type cheese manufactured using a freeze-dried Tibetan kefir co-culture during ripening. Food Sci. Biotechnol., 24(2), 393-402. http://dx.doi.org/10.1007/ s10068-015-0052-9

Mistry, V. V. (2001). Low fat cheese technology. Int. Dairy J., 11, 413-422. https://doi.org/10.1016/S09586946(01)00077-2

Nelson, B. K., Barbano, D. M. (2004). Reduced fat cheddar cheese manufactured using a novel fat removal process. J. Dairy Sci., 87, 841-853. https://doi.org/10.3168/jds. S0022-0302(04)73228-2

Pilar, L., Fuente, M. A., Juárez, M. (2005). Conjugated linoleic acid in processed cheeses during the manufacturing stages. J. Agric. Food Chem., 53, 7, 2690-2695. https://doi.org/10.1021/jf048091x

Pluta, A., Berthold, A., Kielak, J. (2006). Zmiany wybranych cech fizykochemicznych, reologicznych i sensorycznych w czasie dojrzewania sera typu holenderskiego różnej zawartości tłuszczu. Żywn. Nauka Technol. Jakość, 2, 47, 255-261.

Polentarutti, M., Piasenzotto, L., Comi, G., Conte, L., Surmely, A. (2001). Influence of season on raw milk and on Montasio cheese aroma. Ind. Aliment., 409, 1331-1342.

Slots, T., Butler, G., Leifert, C., Kristensesn, T., Skibsted, L. H., Nielsen, J. N. (2009). Potential to differentiate milk composition by different feeding strategies. J. Dairy Sci., 92, 2057-2066. https://doi.org/10.3168/jds.2008-1392

Yildirim, M., Gulec, F., Bayram, M., Yildirim, Z. (2006). Properties of Kashar cheese coated with casein as a carrier of natamycin. Ital. J. Food Sci., 2, 18, 127-138.

Yvon, M., Rijnen, L. (2001). Cheese flavour formation by amino acid catabolism. Int. Dairy J., 11, 185-201.

Wallace, J. M., Fox, P. F. (1997). Effect of adding free amino acids to Cheddar cheese curd onproteolysis, flavour and texture development. Int. Dairy J., 7, 157-167. https:// doi.org/10.1016/S0958-6946(96)00049-0 